\title{
Financial Performance Analysis of Scheduled Commercial Banks in Bangladesh
}

\author{
Mohammad Mizanur Rahman \\ Faculty of Business Studies (FBS), Bangladesh University of Professionals (BUP), Bangladesh
}

Copyright $(2016$ by authors, all rights reserved. Authors agree that this article remains permanently open access under the terms of the Creative Commons Attribution License 4.0 International License

\begin{abstract}
The purpose of this study is to provide a comprehensive financial performance evaluation of scheduled commercial banking companies in Bangladesh. The nature of this study is descriptive and relational. This inductive research uses financial ratio analysis technique of cross- sectional data to measure, describe and analyze the financial performance of publicly traded commercial banks in Bangladesh. The financial performance issue has been grouped into profitability ratio, market ratio, and value added metrics for the assessment of internal based, market -based, and economic based performance respectively. Ranking of banks has been done on the basis of financial performance in the period of 2015; and it has been found that Dutch Bangla Bank Ltd. is one of the leading banks. The study findings have revealed that most of the banks except a few have shown poor economic performance, negative economic value added (EVA), and undervalued market price per share. The study findings have also shown the significant correlation between "EVA and Profitability Ratio" and "EVA and Market Ratio", and termed EVA as an independent measure of performance. The concerned research on evaluation of financial performance has covered mainly publicly traded commercial banking companies in Bangladesh only certain time duration, and therefore has raised the issue of generalization of the results. The analysis of financial performance is used by most of the business communities. So, the study findings may provide useful guidance for trade creditors, management for banks, and the general investors. In addition, the assessment of bank's financial performance can be a useful source of information for the Bangladesh government's policy makers.
\end{abstract}

Keywords Financial Performance, Scheduled Commercial Banks, Economic Value Added

\section{Introduction}

Bank is a financial intermediary. It channels the funds from the surplus unit to the deficit unit continuously. It is expected that for sustainable intermediation function, banks need to be profitable. Ongore \& Kusa [1] says, beyond the intermediation function, the financial performance of banks has important implications for economic growth of the country. Sound and healthy financial performance of the banks rewards the shareholders for their investment and vice - versa. This, in turn, encourages additional investment and brings about economic growth. In the past shareholders of joint stock companies were treated as merely investors in the company's fortunes and required to be paid simply dividend. Company's management focused on pay dividend rather than maximizing wealth for its shareholders. However, Parasuraman [2] states, now professional managers feel a need to satisfy not only shareholders and the Board of Directors, but also stakeholders including potential investors. As a result, the pressure is on the corporate sector to prove to their stakeholders that indeed their wealth out of the investment has increased. Thus issues involved are relating to financial performance measures.

Financial performance analysis of commercial banks has been of great interest to academic research since the great depression interns the 1940's. The measurement of financial performance of commercial banks is well researched; a large number of empirical studies have been conducted regarding commercial bank's performance around the world [3-7]. However, a little attention has been paid on bank's performance in Bangladesh. This study evaluates bank's financial performance for the phase of 2015 using financial ratio analysis (hereafter FRA). It is justified to conduct a study on financial performance of banks because we have seen that currently the banking sector of Bangladesh has left about BDT 90,000 core as idle money.

Financial performance is a broad concept; it includes economic growth, return, and productivity. Financial Performance means a general measure of a company's financial health over a given period of time. It is the most important economic characteristic that defines the competitiveness of companies. Companies must be capable of evaluating their performance accurately in order to understand their financial status and future prospects. Yalcin, Bayrakdaroglu, \& Kahraman [8] have found that 
performance assessment using the financial ratios can be appropriate for companies and their counterparts. The study favors FRA because of its effectiveness in distinguishing high performance banks from the others; FRA also enables to identify unique bank strengths and weaknesses. Evaluating financial performance is indispensable because the survival of an organization depends on its ability to both evaluate current financial position and future risks \& potentials. Thus performance evaluation facilitates the firm to identify strategies to improve the quality of planning and controlled decisions. The purpose of measuring financial performance evaluation is to know how the business is performing, understand its strengths and weaknesses. This evaluation gives an indication what changes to make to achieve higher returns, and enable the firm to perform better if possible with less risk. As financial performance measures the company's strategy and its implementation and execution effectively contributing towards profitability, liquidity, efficiency, and solvency so that the business can be carried out smoothly. Hence the present study takes an attempt to conduct descriptive analysis of the financial performance in the banking sector of Bangladesh.

The scope of the study is it has covered only 28 banks that are listed in Dhaka Stock Exchange Ltd. (DSE) and Chittagong Stock Exchange Ltd. (CSE), Bangladesh. Out of 28 banks we have found one Nationalized Commercial Bank, 05 (five) Islamic Banks, and 22 (twenty two) Private Commercial Banks. Neither any Foreign Commercial Banks nor Specialized Banks have been covered in the study. In addition, the study has covered only the year of 2015 .

The principal purpose of this study is to evaluate financial performance of publicly traded commercial banks in Bangladesh. The basic research question is to see which banks have done excellent financial performance. Another purpose of the study is to seek relationship between traditional accounting based performance measures and modern value based performance measures. This study has taken an attempt to update the extant literature related to the financial performance measures in banking sector of Bangladesh.

\section{Introduction about Banking Industry in Bangladesh}

The banking industry in Bangladesh is mixed one comprising nationalized, private, and foreign commercial banks. After the independence, banking industry in Bangladesh started its journey with 6 nationalized commercialized banks, 2 State owned specialized banks and 3 Foreign Banks. In the 1980's banking industry achieved significant expansion with the entrance of private banks. Now, banks in Bangladesh are primarily of two types.

\subsection{Scheduled Banks}

The banks which get license to operate under Bank
Company Act, 1991 (Amended up to 2013) are termed as Scheduled Banks. Scheduled Banks are classified into following types:

- State Owned Commercial Banks (SOCBs): There are 6 SOCBs which are fully or majorly owned by the Government of Bangladesh.

- Specialized Banks (SDBs): 2 specialized banks are now operating which were established for specific objectives like agricultural or industrial development. These banks are also fully or majorly owned by the Government of Bangladesh.

- Private Commercial Banks (PCBs): There are 39 private commercial banks which are majorly owned by the private entities. PCBs can be categorized into two groups:

- Conventional PCBs: 31 conventional PCBs are now operating in the industry. They perform the banking functions in conventional fashion i.e. interest based operations.

- Islami Shariah based PCBs: There are 8 Islami Shariah based PCBs in Bangladesh and they execute banking activities according to Islami Shariah based principles i.e. Profit-Loss Sharing (PLS) mode.

- Foreign Commercial Banks (FCBs): 9 FCBs are operating in Bangladesh as the branches of the banks which are incorporated in abroad.

So, there are 56 scheduled banks in Bangladesh who operate under full control and supervision of Bangladesh Bank which is empowered to do so through Bangladesh Bank Order, 1972 and Bank Company Act, 1991.

\subsection{Non-scheduled Banks}

The banks which are established for special and definite objectives, and operate under the acts that are enacted for meeting up those objectives, are termed as Non-Scheduled Banks. These banks cannot perform all functions of scheduled banks. There are now 4 non-scheduled banks in Bangladesh which are Ansar VDP Unnayan Bank, Karmashangosthan Bank, Probashi Kollyan Bank, and Jubilee Bank.

\section{Description of Financial Performance Measures}

In this study, financial performance measures are divided into two groups: Traditional Accounting Based Performance Measures and Modern Value Based Performance Measures.

\subsection{Traditional Accounting Based Performance Measures}

\subsubsection{Return on Assets (ROA)}

ROA indicates the productivity of assets that means how much net income or profit a company is able to earn for each 
BDT of assets invested. Khrawish [9] says, it further indicates the efficiency of the management of a company in generating net income from all the resources of the institution. Moyer, McGuigan, Rao, \& Kretlow [10] have given a formula which can be calculated:

$$
\mathrm{ROA}=\mathrm{EBIT} \div \text { Average Assets }
$$

In this study net income and total assets figure have been taken from profit and loss account and balance sheet respectively. However, the amount of average assets is used in replace of total assets in calculating ROA. Wen [11] states that a higher ROA shows the company is more efficient in using its resources. According to Basel-II accord, ROA should be more than $1 \%$.

\subsubsection{Return on Investment (ROI)}

The measure of Return on Investment is a very popular metric because of its versatility and simplicity. Essentially, ROI can be used as a rudimentary gauge of an investment's profitability. If an investment does not have a positive ROI, or if an investor has other opportunities available with a higher ROI, then these ROI values can instruct investors as to which investments are preferable to others. ROI is computed in the following process:

$$
\begin{gathered}
\text { ROI }=\text { Profit After Tax }(\text { PAT }) \div \text { Average Equity, } \\
\text { Long Term Borrowings and Deposits }
\end{gathered}
$$

\subsubsection{Return on Equity (ROE)}

This ratio indicates how bank can generate profit with the money shareholders have invested. The higher value of this ratio shows higher financial performance. Like ROA, this ratio is also indicator for managerial efficiency. According to Kieso, Weygandt, \& Warfield [12] return on Equity is computed by dividing net income less preferred dividend by average company stockholders equity. Higher value of ROE is an indication of high productivity of equity.

\subsubsection{Net Interest Margin (NIM)}

Another important means to indicate the earning and profitability measure is Net Interest Income (NIM). Net interest Margin is the spread between interest receipts from loans and advances and interest paid to the depositors. The high NIM means the spread between interest receipts and paid is high. The higher the net interest margin, the higher the bank's profit and the more stable the bank is. However, Khrawish [9] says, a higher net interest margin could reflect riskier lending practices associated with substantial loan loss provisions.

\subsubsection{Earnings per Share (EPS)}

Earnings per Share indicate company's earnings against each share. The following formula is used:

Earnings per Share: Profit After Tax $\div$ Weighted Average Number of Share Outstanding

\subsubsection{Price Earnings Ratio $(\mathrm{P} / \mathrm{E})$}

This ratio indicates investors' judgment or expectations about the firm's performance. Normally, this ratio reflects investors' expectations about the growth in the firm's earnings. The $\mathrm{P} / \mathrm{E}$ ratio indicates how much investors are willing to pay for buying shares per BDT of current earnings. $\mathrm{P} / \mathrm{E}$ ratio is the most popular measure for performance analysis while there are other factors that an investor should consider before making an investment decision. This value is calculated by using the following formula:

$\mathrm{P} / \mathrm{E}$ Ratio $=$ Market Value per Share $\div$ Earnings per Share

\subsubsection{Tobin's Q}

Alkhatib \& Harasheh [13] uses the following formula to determine the Tobin's Q ratio.

$$
\text { Tobin's Q = Market Value of Assets :- }
$$

$\div$ (The Market Value of Equity + Book Value of Total Debt)

It is assumed that company is undervalued and overvalued when Tobin's Q is below 1 and above 1 respectively. See Appendix - 2.

\subsubsection{Net Profit}

Net profit refers to the excess of income over expenditure in a given period of time. It is a result of two functions: Revenue Function and Cost Function. The revenue function shows the total income of a bank earned through its activities while cost functions show the total expenditure incurred in a given year. It is an absolute measure of performance of a bank. In this analysis net profit means net profit after provision for taxation and depreciation.

\subsubsection{Dividend Yield}

The Dividend Yield, The dividend yield ratio annualizes the quarterly dividend declared by the company in 2015 .

\section{Dividend Yield $=$ Annualized Dividend per Share $\div$}

$$
\div \text { Market Value per Share }
$$

Above ratio evaluates the shareholders return in relation to the market value of the share.

\subsection{Modern Value-based Performance Measures}

\subsubsection{Value Added Statement}

It is the wealth created by banking services. Value created from the income from banking services is the excess of cost of service rendered. The value added statement shows the total wealth created, how it was distributed to meet certain obligations and reward those responsible for its creation, and the portion retained for the continued operation and expansion of the Bank.

\subsubsection{Economic Value Added (EVA)}

Economic value added (EVA) is a financial performance method to calculate the true economic profit of the bank. It 
provides a measurement of a company's economic success or failure over a period of time, and suggests how much value created by the Banks. Such a yardstick is useful to investors who wish to retain their fund for better earnings as compared to other industries. Shareholders are always worried about value addition of their share. Brewer, Chandra, \& Hock [14] states, EVA is a measure to assess the extent to which companies have succeeded in achieving the objective of enhancing shareholders' wealth. The concept of EVA was developed and presented by a US based consulting firm named Stren Stewart \& Co. for the first time. It is now considered the base for theory of evaluating enterprise value. EVA is an accounting-based, single period measure of corporate performance and there are some ways to calculate EVA that can be explained as follows:

One way to calculate EVA for each year is to multiply company's economic book value of capital ' $\mathrm{C}$ ' at the beginning of the year by the difference between its return on Capital ' $\mathrm{r}$ ' and it cost of capital ' $\mathrm{k}$ ' and It can be written as follows. This formula is suggested by Kramer \& Peters [15].

$$
\mathrm{EVA}_{\mathrm{t}}=\left(\mathrm{r}_{\mathrm{t}}-\mathrm{k}_{\mathrm{t}}\right) \times \mathrm{C}_{\mathrm{t}-1}
$$

Another way we can measure the EVA. As EVA is the measure of value generated from funds invested by the equity holders; so we can measure the EVA considering the difference between Net Operating Profit after Tax (NOPAT) of a firm and its cost of capital:

$$
\mathrm{EVA}_{\mathrm{t}}=\mathrm{NOPAT}_{\mathrm{t}}-\left(\mathrm{k}_{\mathrm{t}} \times \mathrm{C}_{\mathrm{t}-1}\right)
$$

\subsubsection{Market Value Added (MVA)}

Unlike EVA, which measures internal performance, market value added (MVA) is a measure of external performance that indicates how the market has evaluated the company's performance in terms of market value of shares compared to book value of shares. Hartman [16] states that generally MVA is the present value of a series of EVA values or in the presence of excess of capital invested by shareholders. According to Stewart III [17] it is a measure of value created by management. Also is the best external measure of management performance in the long term. Market Value Added (MVA) is the difference between the total market value (based on the price quoted in the main bourse of the company) of equity and the total book value of equity of the bank as at the reporting date.

Positive and higher MVA indicates that the bank has created substantial wealth for its shareholders, and the market is confident in sustainable and progressive business $\&$ profit growth and cash flows of the Bank. On the other hand negative MVA indicate that wealth of the bank is lower than the capital contributed by the investors.

\section{Literature Review}

In this section of the study will introduce some relevant researches with concepts and their findings evolved by earlier researchers. It will also help to rationalize the study gap that identified for present study and to frame appropriate objectives for the proposed evaluation. The present study is to measure the financial performance of commercial banks in Bangladesh. There are two systematic approaches along with alternate methods such as non-parametric DEA and parametric Stochastic Frontier Approach available to measure the banks performance. First one is accounting approach that is used by Ncube [18] which primarily based on the use of financial ratios and the other is econometric technique.

Samad [19] and Van Horne \& Wachowicz Jr. [20] use financial ratio as a checkup tool for measuring the financial performance of firms .Similarly, Pandey [21] asserts that to know about the financial performance of a firm whether it is improved, deteriorated, or remain constant over time easiest way to compare of that firm's present financial ratio with the past. But, Khan [22] emphasizes on profit that shareholders receive from the bank. If the profit along with effectively controlled the relevant risks is more, the bank is identified as successful. Mujeri \& Younus [23] study findings states that interest rate spread is significantly influenced by classified loan and operating cost, inflation, operating cost, market share of deposit, statutory reserve requirement; and taxes is important measure of financial performance. Chowdhury \& Ahmed [24] while measuring financial performance of banking industry in Bangladesh observes steady growth rate of branches, employee, deposit, loans and advances, net income, and EPS during the period of 2002 - 2006. A study has conducted by the European Central Bank in which the study favors financial ratios such as ROA, P/B ratio, and economic based performance rather than using ROE, to analyze performance in terms of bank's capacity to generate sustainable profitability. The study ends up with comprehensive conclusion that performance analysis should employ more forward-looking proxies while taking into account risk and profitability. Duncan \& Elliott [25] study findings shows a positive correlation between customer satisfaction and financial performance measures such as net interest margin, ROA, and capital adequacy. $[26,27]$ use ROA as performance proxy to examine the financial performance measure of Jordanian and Pakistani's commercial banks respectively. However, Tobinq's model is used by Siddiqui \& Shoaib [28] as proxy of determining bank's performance. Their findings reveal that profitability of the bank measured by ROE and Tobin's Q are affected significantly by the size of the bank.

As a reference of econometric approach, the multiple regression analysis technique that has been used by Tarawneh [7] to examine the financial performance measure of Omani commercial banks can be included. In his study, ROA and Interest income are used as performance proxies.

On the other hand, [29-32, 18] follow Stochastic Frontier Approach (SFA), distribution free approach and SFA method, Bayesian SFA, DEA, and SFA method respectively. Their studies follow alternative method and concentrated on to investigate cost and productive efficiency of South African's bank. 
The present study has used profitability ratio, market ratio, and value added metrics to examine the financial performance of banks. Because those ratios have been found by the prior studies mentioned above. In addition, the study has taken an attempt to establish relationship EVA with profitability ratio, market ratio. Because, a little attention has been paid on EVA, an important management tool is now being considered in corporate world, except the study conducted by Mohammad Jahur \& Riyadh [33] and Shill [34]. Their study findings suggest that EVA is an important measure to judge a bank's performance in view of the scenario of banks having to satisfy large number of shareholders. They have found that EVA has statistically significant relationship with other parameters of performance measures such as ROA, Net Profit, and Profit Per employee, and Deposit per Employee.

According to prior studies mentioned above the following hypotheses has been considered:

Hypothesis 1: There is a significant correlation between "EVA and Profitability Ratio".

Hypothesis 2: There is a significant correlation between "EVA and Market Ratio".

\section{Methodology of the Study}

The present study is a descriptive and relational correlated type. An inductive research approach has been used for this study. This empirical study is primarily based on quantitative secondary data obtained from published annual report of respective commercial bank's website for the year of 2015. So, another type of present study is cross-sectional one as per time reference in research. Bowen, Wiersema [35] says using cross - sectional data has some disadvantages. However, it helps to study the performance of the banks very well.

All the licensed commercial domestic and foreign banks currently operating in Bangladesh are the target population of this study. The unit of analysis of this study is the entire commercial domestic and foreign banks listed in both Dhaka Stock Exchange (DSE) and Chittagong Stock Exchange (CSE). The total number of 29 commercial banks have found in DSE. In this study, 28 commercial banks have been considered for analysis purpose. Only one bank excluded because this bank has not listed in CSE yet. Out of 28 banks only one bank named Rupali Bank Ltd. has found state owned, and none of the banks are foreign commercial banks.

The secondary data have been collected using data collection sheet at the end of year, 2015. The purpose with the data is to do some descriptive analysis for the assessment of bank's financial performance. The data have been edited (if necessary), coded and cleaned. After that the data have been analyzed using Statistical Package for Social Sciences (SPSS) software, version 20. The selection of the FRA method for this study has been motivated because of its some advantages. The main advantage of FRA is its ability and effectiveness in distinguishing high performance banks from the others and the fact that FRA compensates for disparities and controls for any size effect on the financial variables being studied Samad [19]. Additionally, financial ratios can be used to identify a bank's specific strengths and weaknesses as well as providing detailed information about bank profitability, liquidity and credit quality policies [36, 37].

The final ranking of the 28 commercial banks selected as a sample has been done on the basis of internal based, market based, and economic based performance respectively; and separate rank has been given for each of the above mentioned parameters. Non-parametric test, the rank correlation coefficient has been used to test the hypotheses. The purpose to test the hypotheses is to see whether correlation coefficients between measures are significant or not. According to Levin \& Rubin [38] the choice of using rank correlation coefficient has some advantages over parametric correlation coefficient. Firstly, it does not consider whether the data are normally distributed or not, secondly it is less sensitive to extreme values in the data set. Finally, we do not need to count sample size which is below thirty for this study. The formula of rank correlation coefficient is as follows:

$$
r_{k}=1-\frac{6 \sum \mathrm{d}^{2}}{n\left(n^{2}-1\right)}
$$

Where, $\mathrm{r}_{\mathrm{k}}=$ Rank correlation co-efficient

$\mathrm{d}=$ the difference between the two ranks

$$
\mathrm{n}=\text { number of observations }
$$

The present study has ensured research quality by focusing on the validity and reliability of the data. The financial and quantitative aspect of the research is based on relevant financial metrics that are suitable to answer the research question. ROA, ROI, ROE, and NIM are profitability metrics that have been used to assess internal based performance. Similarly, EPS, P/E Ratio, BVPS and Tobin's Q for market metrics, and EVA, MVA, NAV per Share, Market Capitalization and Dividend Yield\% for value added metrics have been used to asses market based and economic based performance respectively. By combining profitability ratio, market ratio, and value added metrics the aim is to gain insight into the performance situation of the respective banks. Reliability issue is concerned with the consistency of the findings of research. In order for research to be reliable, other researchers should be able to replicate it and get the same result. The study has used the data from the public sources, company's website. This means that if others could review the data, they would get the same results as well.

\section{Data Analysis and Findings}

\subsection{Characteristics of Variables}

A Shapiro - Wilk's test $(\mathrm{p}>0.05)[39,40]$ and a visual inspection of variables histograms, normal Q-Q plots, and 
box plots have showed that ROA, ROI, ROE, EVA, MVA, and Dividend Yield\% are approximately normally distributed, with a skewness of $0.290,0,222,-0.098,0.956$, 0.934 , and 0.060 respectively (SE $0.441,0.441,0.441,0.441$, 0.441 , and 0.441 respectively) and kurtosis of $0.564,1.015$, $-0.39,0.846,2.904$, and -0.972 respectively (SE 0.858 , $0.858,0.858,0.858,0.858$, and 0.858 respectively ) [41-43]. On the other hand, Test of Normality have showed that NIM, EPS, P/E Ratio, BVPS, Tobin's Q, NAV Per Share, and Market Capitalization do not follow normal distribution because of their respective ' $p$ ' values are below 0.05 , and their skewness and kurtosis values are also far away from the benchmark value of zero "See Appendix - 9".

\subsection{Description of Banks Performance}

Appendix - 4 shows the financial performance of commercial banks as expressed profitability ratio, market ratio, and value added metrics for the year of 2015. As can be observed from the Appendix - 4, the average profitability ratios that means ROA, ROI, ROE, and NIM for the sector as a whole is $1.03 \%, 8.94 \%, 12.10 \%$, and BDT $4,510.47$ million respectively. In addition, the findings also suggest that we can be $95 \%$ confidence about $\mathrm{ROA} \%$, ROI $\%$, and ROE $\%$ that they vary between $0.13 \%$ to $1.92 \%, 0.08 \%$ to $17.80 \%$, and $3.59 \%$ to $20.61 \%$ respectively. Compared to neighboring country like India this performance is average. As per report of RBO, India [44] the vast country like India where private sector's banks average ROA, ROE, and NIM are $1.68 \%, 15.74 \%$, and $2.6 \%$ respectively in the financial year of 2014-2015.

On the other hand, the average EPS, $\mathrm{P} / \mathrm{E}$ ratio, Book Value Per Share (BVPS), Economic Value Added (EVA), Market Value Added (MVA), Tobin's Q are BDT 2.98, 8.25, BDT 24.96, BDT 1,069.79 million, BDT -4078.34 million, and 0.96 respectively. Additional information about EPS can be given as 95 times out of 100 times, EPS will fall between BDT -2.07 to BDT 8.03. It is interesting to note that average market value added for this sector is negative. This is because of bad market response, which in turn has made most of the banks undervalued. Almost all the banks market value per share is far below from the book value per share. This scenario could be better understandable by the ratio of Tobin's Q.

Finally, Appendix - 11 is the presentation of bank performance in terms of market capitalization. During the year of 2015, total market capitalization in Dhaka Stock Exchange (DSE) was BDT 31, 59,757.75 million. Out of 28 banks Islami Bank Bangladesh Ltd. has secured the highest percentage, $1.42 \%$, of total market capitalization in DSE.

\subsection{Assessment of Financial Performance of the Selected Banks}

The various ratios have been used which are categorized into profitability ratio, market ratio, and value added metrics for the analysis. The ratios have been calculated for the period of one year, 2015. Appendix 1- 3 depicts the results of ratio analysis. Points have been given against each types of ratio to the corresponding bank; hence each ratio type produces different rank for the banks. Appendix - 5 represents the descriptive statistics of each bank specific measurements (ratios) that establish the financial performance. Finally, the banks have been ranked on the basis of CV\% of total point score "See Appendix - 8".

Appendix -6 and Appendix - 7 depicts the picture of bank performance on the basis of profitability ratio, market ratio and value added metrics respectively. These categories have been prepared for the stakeholders who are interested to see performance in relation to either of three categories of ratios mentioned above. The study findings reveal that as per profitability ratio the top five banks are Premier Bank Ltd., One Bank Ltd., South East Bank Ltd., Dutch Bangla Bank Ltd., and Al-Arafah Bank Ltd respectively. On the other hand, market based and economic based performance ratios suggest that Brack Bank Ltd., Dutch Bangla Bank Ltd., Dhaka Bank Ltd., Bank Asia Ltd., and Shahjalal Islami Bank Ltd. are the top five banks. Moreover, it is interesting to point out that the rank of Rupali Bank Ltd. has fallen in 28 for profitability ratio and 27 for market and value added metrics ratio.

Appendix - 8 shows the banks that have fallen into ranks ranges from 1 to 28 on the basis of all ratio types. Dutch Bangla Bank Ltd. has been ranked first because of its highest total point score of 303 with lowest $\mathrm{CV} \%$ of 24.62 . Next lowest CV\% of $29.48 \%$ that belongs to Pubali Bank Ltd. with total point score of 224; and it has secured second position. In this way the other banks have been ranked. The study findings have revealed that the top five banks are Dutch Bangla Bank Ltd., Pubali Bank Ltd., Brack Bank Ltd., Bank Asia Ltd., and Uttara Bank Ltd. respectively. Out of 28 banks the position of Rupali Bank Ltd. is 28. It performs poorly; and this bank's financial ratios are low in comparison to the other banks except the ratios of P/E, Tobinq's, NAV, and MVA.

It has been noted that the all types of ranking including final ranking for the banks have been calculated on the basis of $\mathrm{CV} \%$ of total point score not the total point score. Lower $\mathrm{CV} \%$ of particular bank indicates that financial performance in respect to all the ratios is consistent and does not fluctuate much. It would be misleading ranking if we had considered total point score to rank the banks.

\subsection{Relationship between Traditional Accounting Based Performance Measures and Modern Value Based Performance Measures}

In this section of the study, we have taken Economic value added (EVA) as a proxy variable for modern value based performance measures; and ROA, ROE, EPS, P/E have been selected as a proxy variables for traditional accounting based performance measures. Then, seek relationship modern value based performance measures with traditional accounting based performance measures. The relationship 
between EVA of the selected banking companies and variables of accounting measures has been studied and compared with prior research findings. It has been observed that EVA and variables of accounting measures have produced different in ranking for the selected banks; hence there is a difference in ranking between EVA and accounting based performance measures. This finding has led the researcher to note that EVA is independent performance measures to a higher extent which is also the study finding of Jahur and Riyadh [33]. In this section, with the help of rank correlation coefficient, the study has examined whether EVA has significant relationship or not with the variables of accounting based performance measures. It is to be noted that ROA and ROE act as proxy variables for profitability ratio, and EPS and P/E ratio serve as proxy variables for market ratio.

The results of rank correlation coefficient between EVA and variables of accounting measures have showed in Appendix - 10. A kind perusal of the Appendix - 10 reveals that there is a significant correlation between EVA and the measures of profitability ratio. Significant correlation coefficients between "EVA and ROA", "EVA and ROE" have been found at $1 \%$ level of significance. On the other hand, EVA has also established significant correlation with market ratio; EVA is significant with EPS and P/E ratio at $5 \%$ level of significance. These significant relationships are similar to the study findings of Jahur \& Riyadh [33].

The above statistical results have provided enough evidence to reject the null hypothesis that there is no significant correlation between "EVA and Profitability Ratio" and "EVA and Market Ratio".

EVA, however, a moderate degree of correlation, has established with ROA, ROE, EPS, and P/E ratio. In that case, EVA is defined as significant independent measures of performance. It is expected that higher ROA leads to produce higher EVA but only a bank named "One Bank Limited" has a negative EVA although it has ROA more than $1 \%$.

\section{Summary and Conclusions}

This paper has examined the financial performance of publicly traded Bangladeshi commercial banks over the period of 2015 using financial ratio analysis. A company's financial performance is normally judged by a series of ratios. The profitability ratio- a financial metrics- and market ratio indicate firm's capacity to make a profit and the exact position in the market respectively. On the other hand, value added metrics evaluates the economic based performance measure. Financial ratios serve as useful quantitative financial information for investors and for stakeholders so that companies can be appraised over time. In this context, the profitability ratio, the market ratio, and value added metrics have been used in assessing performance. The above analysis has led the researcher to conclude that the financial performance of Dutch Bangla Bank Ltd. is extremely good in comparison to the other banks considering all types of ratio. All the banks managed to log in profits for 2015 despite a tough start to the year by way of political turmoil for the first three months and the export and import business and this avenue too was not kind to them. In other words, the export-import growth has been slowed. Furthermore, lower bank's interest rate spread, reduced various commission, and stable foreign exchange rate made the banks gain brought down. As a result, the banks' profit did not increase much in 2015. Having been experienced challenges, National Bank Bangladesh Limited registered the highest profit among banks in 2015, of BDT 3,854 core. And City Bank Limited, which is another large bank, logged in BDT 3,579 core in profit in 2015. The study findings have revealed that most of the banks market performance is not satisfactory as they were undervalued in the market and added negative value to the market meaning that they had to struggle a lot during this period. However, except a few, most of the banks have offered cash dividend which is an indication that bank generates enough profit to its shareholders. In addition, it has also been found in the study that EVA is an important independent measure to judge the banks performance. The results of this study will serve as a starting point for future research. 


\section{Appendix}

\section{Appendix - 1}

\begin{tabular}{|c|c|c|c|c|}
\hline \multirow[b]{2}{*}{ Name of the Banks } & \multicolumn{4}{|c|}{ Profitability Ratio (Based on Investment) } \\
\hline & $\begin{array}{l}\text { Return on Assets } \\
\text { (ROA) } \%\end{array}$ & $\begin{array}{l}\text { Return on Investment } \\
\text { (ROI) } \%\end{array}$ & $\begin{array}{l}\text { Return on Equity } \\
\text { (ROE) } \%\end{array}$ & $\begin{array}{c}\text { Net Interest Margin } \\
\text { (NIM) } \\
\text { (BDT in million) }\end{array}$ \\
\hline AB Bank Ltd. & 0.48 & 10.49 & 6.03 & 4,279 \\
\hline City BanK Ltd. & 1.8 & 7.5 & 14.7 & 5,506 \\
\hline Al Arafah Islami Bank Ltd. & 0.99 & 11.70 & 12.82 & $7,494.99$ \\
\hline Social Islami Bank Ltd. & 2.08 & 3.93 & 16 & $6,290.88$ \\
\hline Pubali Bank Ltd. & 1.01 & 11.64 & 11.64 & $6,774.84$ \\
\hline Premier Bank Ltd. & 0.79 & 6.33 & 9.39 & $2,348.13$ \\
\hline Prime Bank Ltd. & 0.84 & 11.80 & 8.41 & 1,294 \\
\hline Exim Bank Ltd. & 0.88 & 1.82 & 9.06 & $7,854.03$ \\
\hline Dutch Bangla Bank Ltd. & 1.3 & 10.4 & 19.3 & 9,788 \\
\hline Islami Bank BD Ltd. & 0.44 & 8.20 & 6.4 & $19,307.55$ \\
\hline National Bank Ltd. & 1.43 & 13.84 & 12.74 & 2,933 \\
\hline IFIC Bank Ltd. & 0.53 & 6.48 & 18.46 & $3,774.5$ \\
\hline Rupali Bank Ltd. & 0.08 & 8.32 & 2.52 & $(1,733)$ \\
\hline Uttara Bank Ltd. & 0.99 & 12.44 & 11.42 & $2,863.59$ \\
\hline Eastern Bank Ltd. & 1.23 & 2.25 & 10.95 & 3,545 \\
\hline Dhaka Bank Ltd. & 0.86 & 14.83 & 10.74 & 2,018 \\
\hline NCC Bank Ltd. & 0.97 & 11.25 & 9.12 & $3,090.17$ \\
\hline Standard Bank Ltd. & 1.83 & 21.07 & 18.87 & 2,168 \\
\hline Mutual Trust Bank Ltd. & 1.04 & 9.93 & 17.40 & 2,864 \\
\hline South East Bank Ltd. & 1.23 & 8.84 & 11.86 & $3,265.57$ \\
\hline One Bank Ltd. & 1.39 & 11.32 & 16.60 & $4,563.15$ \\
\hline Shahjalal Islami Bank Ltd. & 0.98 & 1.64 & 10.78 & 3,567 \\
\hline Jamuna Bank Ltd. & 1.16 & 10.13 & 12.39 & $1,617.93$ \\
\hline Brack Bank Ltd. & 1.13 & 6.13 & 13.32 & 8,716 \\
\hline Trust Bank Ltd. & 0.85 & 11.06 & 17.45 & 100.42 \\
\hline First Security Islami Bank Ltd. & 0.35 & 0.80 & 6.44 & $5,257.78$ \\
\hline Bank Asia Ltd. & 1.26 & 7.44 & 14.36 & $2,707.44$ \\
\hline Mercantile Bank Ltd. & 0.79 & 8.70 & 9.60 & $2,304.14$ \\
\hline
\end{tabular}

BDT (Bangladesh Taka): The currency abbreviation or currency symbol for the Bangladesh taka (BDT), the currency for Bangladesh. The Bangladesh taka is made up of 100 poisha and is often presented with the symbol ó, ò, or Tk. On December 31,2015 , one US dollar is equal to $78.50 \mathrm{Tk}$. 


\section{Appendix - 2}

\begin{tabular}{|c|c|c|c|c|c|c|c|}
\hline \multirow[b]{2}{*}{ Name of the Banks } & \multicolumn{7}{|c|}{ Market Ratio and Value Added Metrics } \\
\hline & $\begin{array}{c}\text { EPS } \\
\text { (in BDT) }\end{array}$ & $\begin{array}{l}\mathrm{P} / \mathrm{E} \\
\text { Ratio }\end{array}$ & $\begin{array}{c}\text { BVPS } \\
\text { (in BDT) }\end{array}$ & $\begin{array}{c}\text { EVA } \\
\text { (BDT in } \\
\text { million) }\end{array}$ & $\begin{array}{l}\text { MVA } \\
\text { (BDT in } \\
\text { million) }\end{array}$ & Tobin's Q & $\begin{array}{c}\text { Undervalued/ } \\
\text { Overvalued } \\
\text { (Based on Tobin's } \\
\text { Q) }\end{array}$ \\
\hline AB Bank Ltd. & 2.12 & 9.86 & 38.05 & (807) & $(10,270.55)$ & 0.55 & Undervalued \\
\hline City BanK Ltd. & 4.1 & 5 & 29.13 & 1,836 & $(7,642.72)$ & 0.70 & Undervalued \\
\hline Al Arafah Islami Bank Ltd. & 2.34 & 6.28 & 20.31 & $2,936.82$ & $(5,315.78)$ & 0.72 & Undervalued \\
\hline Social Islami Bank Ltd. & 2.95 & 4.89 & 18.42 & $1,435.74$ & $(2,825.08)$ & 0.78 & Undervalued \\
\hline Pubali Bank Ltd. & 3.29 & 6.57 & 28.26 & 486.96 & $(5,859.04)$ & 0.76 & Undervalued \\
\hline Premier Bank Ltd. & 1.55 & 5.24 & 16.52 & $(405.22)$ & $(4,912.13)$ & 0.52 & Undervalued \\
\hline Prime Bank Ltd. & 2.08 & 8.71 & 25.66 & $(463)$ & $(7,784)$ & 0.71 & Undervalued \\
\hline Exim Bank Ltd. & 1.55 & 5.55 & 17.91 & 1,057 & $(13,152.67)$ & 0.48 & Undervalued \\
\hline Dutch Bangla Bank Ltd. & 15.1 & 7.1 & 83.77 & 1,821 & 4,766 & 1.28 & Overvalued \\
\hline Islami Bank BD Ltd. & 1.88 & 14.79 & 29.37 & $(574.62)$ & $(2528)$ & 0.95 & Undervalued \\
\hline National Bank Ltd. & 2.24 & 4.20 & 19.54 & $1,519.74$ & $(17,411.40)$ & 0.48 & Undervalued \\
\hline IFIC Bank Ltd. & 1.76 & 12.03 & 23.15 & $2,451.04$ & (982) & 0.92 & Undervalued \\
\hline Rupali Bank Ltd. & 0.98 & 32.99 & 5.29 & 119.74 & $6,482.44$ & 6.11 & Overvalued \\
\hline Uttara Bank Ltd. & 3.76 & 6.04 & 32.88 & $1,388.06$ & $(4,074.39)$ & 0.69 & Undervalued \\
\hline Eastern Bank Ltd. & 3.63 & 7.87 & 33.54 & $(526.91)$ & $(3,016.35)$ & 0.85 & Undervalued \\
\hline Dhaka Bank Ltd. & 2.3 & 8.57 & 21.41 & 952 & $(1,069.69)$ & 0.92 & Undervalued \\
\hline NCC Bank Ltd. & 1.54 & 5.34 & 17.72 & (191.18) & $(8,350.43)$ & 0.47 & Undervalued \\
\hline Standard Bank Ltd. & 2.66 & 11.35 & 17.50 & 810.23 & $(5,440.69)$ & 0.53 & Undervalued \\
\hline Mutual Trust Bank Ltd. & 3.70 & 5.27 & 24.18 & 514 & $(1,727.34)$ & 0.81 & Undervalued \\
\hline South East Bank Ltd. & 3.35 & 5.25 & 29.67 & $3,561.16$ & $(11,022.83)$ & 0.59 & Undervalued \\
\hline One Bank Ltd. & 3.26 & 4.69 & 19.63 & $4,880.06$ & $(2,553.35)$ & 0.78 & Undervalued \\
\hline Shahjalal Islami Bank Ltd. & 1.76 & 7.69 & 16.68 & 637.38 & $(2,336.01)$ & 0.81 & Undervalued \\
\hline Jamuna Bank Ltd. & 2.67 & 4.52 & 25.58 & $1,873.02$ & $(8,283.65)$ & 0.47 & Undervalued \\
\hline Brack Bank Ltd. & 3.43 & 14.19 & 26.53 & 2,989 & $15,727.70$ & 1.84 & Overvalued \\
\hline Trust Bank Ltd. & 3.28 & 7.35 & 20.29 & 828.16 & $1,786.68$ & 1.19 & Overvalued \\
\hline First Security Islami Bank Ltd. & 1.18 & 7.40 & 14.20 & 288.07 & $(3,665.30)$ & 0.62 & Undervalued \\
\hline Bank Asia Ltd. & 3.07 & 5.38 & 22.61 & 167.56 & $(5,128.12)$ & 0.73 & Undervalued \\
\hline Mercantile Bank Ltd. & 1.88 & 7 & 20.99 & 369.26 & $(7,604.75)$ & 0.51 & Undervalued \\
\hline
\end{tabular}

*EPS = Earnings Per Share, P/E = Price - Earnings Ratio, BVPS = Book Value Per Share, EVA = Economic Value Added, and MVA = Market Value Added 


\section{Appendix - 3}

\begin{tabular}{|c|c|c|c|c|c|c|}
\hline \multirow{3}{*}{ Name of the Banks } & \multicolumn{6}{|c|}{ Other Measures of Financial Performance } \\
\hline & \multirow{2}{*}{$\begin{array}{c}\text { Net Asset } \\
\text { Value Per } \\
\text { Share } \\
\text { (NAVPS) }\end{array}$} & \multicolumn{3}{|c|}{ Market Capitalization } & \multicolumn{2}{|c|}{ Dividend } \\
\hline & & $\begin{array}{l}\text { Market Value } \\
\text { (in BDT) }\end{array}$ & $\begin{array}{l}\text { Total No. of Shares } \\
\text { Outstanding }\end{array}$ & $\begin{array}{c}\text { Market } \\
\text { Capitalization } \\
\text { (BDT in million) }\end{array}$ & $\begin{array}{c}\text { Cash } \\
\text { Dividend\% }\end{array}$ & $\begin{array}{l}\text { Dividend } \\
\text { Yield \% }\end{array}$ \\
\hline AB Bank Ltd. & 38.05 & 20.90 & $599,016,546$ & $12,519.45$ & - & - \\
\hline City BanK Ltd. & 29.1 & 20.40 & $875,798,031$ & $17,866.28$ & 22 & 10.78 \\
\hline Al Arafah Islami Bank Ltd. & 6.36 & 14.70 & $946,958,503$ & $13,920.29$ & 10 & 6.80 \\
\hline Social Islami Bank Ltd. & 18.42 & 14.40 & $703,141,564$ & $10,125.24$ & 15 & 10.42 \\
\hline Pubali Bank Ltd. & 28.26 & 21.60 & $880,373,812$ & $19,016.07$ & 12 & 5.56 \\
\hline Premier Bank Ltd. & 16.52 & 8.6 & $620,073,703$ & $5,208.62$ & - & - \\
\hline Prime Bank Ltd. & 25.66 & 18.10 & $1,029,348,616$ & 18,631 & 15 & 8.29 \\
\hline Exim Bank Ltd. & 17.91 & 8.6 & $1,412,251,068$ & $12,145.36$ & 12 & 13.95 \\
\hline Dutch Bangla Bank Ltd. & 83.8 & 107.6 & $200,000,000$ & $21,520.00$ & 40 & 3.72 \\
\hline Islami Bank BD Ltd. & 29.32 & 27.8 & $160,99,90,668$ & $44,757.74$ & 20 & 7.19 \\
\hline National Bank Ltd. & 19.54 & 9.40 & $1,717,720,000$ & $16,146.57$ & - & - \\
\hline IFIC Bank Ltd. & 23.15 & 21.20 & $503,410,000$ & $10,672.34$ & - & - \\
\hline Rupali Bank Ltd. & 52.94 & 32.30 & $240,033,750$ & $7,753.09$ & - & - \\
\hline Uttara Bank Ltd. & 32.88 & 22.70 & $400,080,337$ & $9,081.82$ & 20 & 8.81 \\
\hline Eastern Bank Ltd. & 33.54 & 28.60 & $611,179,785$ & $17,479.74$ & 20 & 6.99 \\
\hline NCC Bank Ltd. & 17.72 & 8.27 & $883,218,003$ & $7,304.21$ & 12.75 & 14.01 \\
\hline Standard Bank Ltd. & 16.92 & 9.20 & $655,740,785$ & $6,032.82$ & - & - \\
\hline Mutual Trust Bank Ltd. & 24.18 & 19.50 & $369,315,967$ & $7,201.66$ & - & - \\
\hline South East Bank Ltd. & 29.69 & 17.65 & $27,207,000,000$ & $16,184.18$ & $15 \%$ & 8.52 \\
\hline One Bank Ltd. & 19.63 & 15.30 & $589,924,914$ & $9,025.85$ & 12.50 & 8.17 \\
\hline Shahjalal Islami Bank Ltd. & 16.68 & 13.50 & $734,688,133$ & $9,918.29$ & 13 & 9.63 \\
\hline Jamuna Bank Ltd. & 25.58 & 12.09 & $614,119,386$ & $7,424.70$ & 19.50 & 16.25 \\
\hline Brack Bank Ltd. & 26.53 & 48.70 & $709,287,321$ & 34,542 & 25 & 5.13 \\
\hline Trust Bank Ltd. & 20.29 & 24.1 & $468,826,971$ & $11,298.73$ & 7 & 2.90 \\
\hline $\begin{array}{c}\text { First Security Islami Bank } \\
\text { Ltd. }\end{array}$ & 14.20 & 8.8 & $678,873,888$ & $5,974.09$ & 10 & 11.36 \\
\hline Bank Asia Ltd. & 22.61 & 16.50 & $839,300,000$ & $13,848.45$ & 15 & 9.09 \\
\hline Mercantile Bank Ltd. & 20.98 & 10.7 & $739,156,701$ & $7,908.98$ & 12 & 11.21 \\
\hline
\end{tabular}


Appendix - 4

\begin{tabular}{|c|c|c|c|c|c|}
\hline \multicolumn{7}{|c|}{ Descriptive Statistics of Variables } \\
\hline & $\mathrm{N}$ & Minimum & Maximum & Mean & Std. Deviation \\
\hline Return on Assets (in \%) & 28 & .08 & 2.08 & 1.0254 & .44587 \\
\hline Return on Investment (in \%) & 28 & .80 & 21.07 & 8.9386 & 4.42963 \\
\hline Return on Equity (in \%) & 28 & 2.52 & 19.30 & 12.0989 & 4.25479 \\
\hline $\begin{array}{c}\text { Net Interest Margin } \\
\text { (BDT in million) }\end{array}$ & 28 & .00 & $19,307.55$ & $4,510.4682$ & $3,807.03127$ \\
\hline Earnings Per Share (in BDT) & 28 & .98 & 15.10 & 2.9789 & 2.52600 \\
\hline Price Earnings Ratio (P/E) & 28 & 4.20 & 32.99 & 8.2543 & 5.60808 \\
\hline $\begin{array}{c}\text { Book Value Per Share } \\
\text { (in BDT) }\end{array}$ & 28 & 5.29 & 83.77 & 24.9568 & 13.36325 \\
\hline Economic Value Added (BDT in million) & 28 & $(807.00)$ & $4,880.06$ & $1,069.7882$ & $1,370.60643$ \\
\hline $\begin{array}{c}\text { Market Value Added } \\
\text { (BDT in million) }\end{array}$ & 28 & $(1,7411.40)$ & $15,727.70$ & $(4,078.3375)$ & $6,327.70800$ \\
\hline Tobin's Q & 28 & .47 & 6.11 & .9561 & 1.05186 \\
\hline Net Asset Value Per Share (in BDT) & 28 & 6.36 & 83.80 & 26.1382 & 14.29207 \\
\hline $\begin{array}{c}\text { Market Capitalization } \\
\text { (BDT in million) }\end{array}$ & 28 & $5,208.62$ & $44,757.74$ & $13,779.5446$ & $8,669.42946$ \\
\hline Dividend Yield Percentage & 28 & .00 & 16.25 & 6.4939 & 4.90757 \\
\hline Valid N (listwise) & 28 & & & & \\
\hline
\end{tabular}

Appendix - 5

\begin{tabular}{|c|c|c|c|c|c|c|c|c|c|c|c|}
\hline \multicolumn{12}{|c|}{ Descriptive Statistics of All Banks (Descending Order) } \\
\hline & $\mathrm{N}$ & Minimum & Maximum & Sum & Mean & Std. Deviation & Variance & \multicolumn{2}{|c|}{ Skewness } & \multicolumn{2}{|c|}{ Kurtosis } \\
\hline & Statistic & Statistic & Statistic & Statistic & Statistic & Statistic & Statistic & Statistic & Std. Error & Statistic & Std. Error \\
\hline Dutch Bangla Bank Ltd. & 13 & 10.00 & 28.00 & 303.00 & 23.3077 & 5.73563 & 32.897 & -1.306 & .616 & .922 & 1.191 \\
\hline Brack Bank Ltd. & 13 & 6.00 & 28.00 & 276.00 & 21.2308 & 6.72252 & 45.192 & -1.179 & .616 & .853 & 1.191 \\
\hline City Bank Ltd. & 13 & 5.00 & 27.00 & 240.00 & 18.4615 & 7.30999 & 53.436 & -.869 & .616 & -.702 & 1.191 \\
\hline Pubali Bank Ltd. & 13 & 9.00 & 25.00 & 224.00 & 17.2308 & 5.08517 & 25.859 & -.087 & .616 & -1.288 & 1.191 \\
\hline Eastern Bank Ltd. & 13 & 3.00 & 26.00 & 222.50 & 17.1154 & 7.41663 & 55.006 & -.842 & .616 & -.126 & 1.191 \\
\hline Uttara Bank Ltd. & 13 & 10.00 & 26.00 & 221.50 & 17.0385 & 6.14567 & 37.769 & .390 & .616 & -1.596 & 1.191 \\
\hline One Bank Ltd. & 13 & 3.00 & 28.00 & 217.50 & 16.7308 & 7.00778 & 49.109 & -.428 & .616 & -.264 & 1.191 \\
\hline South East Bank Ltd. & 13 & 3.00 & 27.00 & 217.50 & 16.7308 & 7.18974 & 51.692 & -.537 & .616 & -.575 & 1.191 \\
\hline $\begin{array}{l}\text { Islami Bank Bangladesh } \\
\text { Ltd. }\end{array}$ & 13 & 2.00 & 28.00 & 213.50 & 16.4231 & 9.92019 & 98.410 & -.333 & .616 & -1.541 & 1.191 \\
\hline IFIC Bank Ltd. & 13 & 4.00 & 26.00 & 205.00 & 15.7692 & 7.98857 & 63.817 & -.206 & .616 & -1.513 & 1.191 \\
\hline Social Islami Bank Ltd. & 13 & 4.00 & 28.00 & 201.50 & 15.5000 & 7.47774 & 55.917 & -.172 & .616 & -1.014 & 1.191 \\
\hline Al-Arafah Islami Bank Ltd. & 13 & 1.00 & 25.00 & 201.50 & 15.5000 & 6.44205 & 41.500 & -.468 & .616 & 1.002 & 1.191 \\
\hline Trust Bank Ltd. & 13 & 2.00 & 25.00 & 200.00 & 15.3846 & 7.13604 & 50.923 & -.180 & .616 & -.699 & 1.191 \\
\hline Dhaka Bank Ltd. & 13 & 5.00 & 27.00 & 198.50 & 15.2692 & 6.33316 & 40.109 & .325 & .616 & -.579 & 1.191 \\
\hline Prime Bank Ltd. & 13 & 3.00 & 27.00 & 194.00 & 14.9231 & 8.30122 & 68.910 & -.123 & .616 & -1.466 & 1.191 \\
\hline Mutual Trust Bank Ltd. & 13 & 4.00 & 25.00 & 193.50 & 14.8846 & 6.84396 & 46.840 & -.261 & .616 & -.792 & 1.191 \\
\hline Bank Asia Ltd. & 13 & 8.00 & 22.00 & 190.00 & 14.6154 & 4.75287 & 22.590 & .030 & .616 & -1.408 & 1.191 \\
\hline Standard Bank Ltd. & 13 & 3.00 & 28.00 & 175.00 & 13.4615 & 9.76060 & 95.269 & .559 & .616 & -1.505 & 1.191 \\
\hline Jamuna Bank Ltd. & 13 & 1.50 & 28.00 & 172.50 & 13.2692 & 8.46713 & 71.692 & -.016 & .616 & -1.076 & 1.191 \\
\hline AB Bank Ltd. & 13 & 1.00 & 27.00 & 163.00 & 12.5385 & 9.42174 & 88.769 & .277 & .616 & -1.527 & 1.191 \\
\hline $\begin{array}{l}\text { Shahjalal Islami Bank } \\
\text { Ltd. }\end{array}$ & 13 & 2.00 & 21.00 & 160.00 & 12.3077 & 6.62866 & 43.939 & -.205 & .616 & -1.354 & 1.191 \\
\hline National Bank Ltd. & 13 & 1.00 & 26.00 & 159.50 & 12.2692 & 8.72405 & 76.109 & .224 & .616 & -1.249 & 1.191 \\
\hline Rupali Bank Ltd. & 13 & 1.00 & 28.00 & 144.00 & 11.0769 & 11.69374 & 136.744 & .705 & .616 & -1.475 & 1.191 \\
\hline Mercantile Bank Ltd. & 13 & 5.00 & 24.00 & 139.00 & 10.6923 & 4.95201 & 24.522 & 1.703 & .616 & 3.742 & 1.191 \\
\hline Exim Bank Ltd. & 13 & 2.00 & 26.00 & 138.00 & 10.6154 & 8.01861 & 64.298 & .974 & .616 & -.109 & 1.191 \\
\hline NCC Bank Ltd. & 13 & 1.50 & 27.00 & 120.50 & 9.2692 & 7.21288 & 52.026 & 1.547 & .616 & 2.113 & 1.191 \\
\hline $\begin{array}{l}\text { First Security Islami Bank } \\
\text { Ltd. }\end{array}$ & 13 & 1.00 & 25.00 & 112.00 & 8.6154 & 8.30199 & 68.923 & .856 & .616 & -.686 & 1.191 \\
\hline Premier Bank Ltd. & 13 & 1.00 & 13.00 & 75.00 & 5.7692 & 2.99733 & 8.984 & .891 & .616 & 1.938 & 1.191 \\
\hline Valid N (listwise) & 13 & & & & & & & & & & \\
\hline
\end{tabular}


Appendix - 6

\begin{tabular}{|c|c|c|c|c|c|}
\hline \multirow{2}{*}{ Name of the Banks } & \multicolumn{5}{|c|}{ Banks Financial Performance (Based on Profitability Ratio) } \\
\hline & Total Point Score & $\begin{array}{l}\text { Mean } \\
\text { Score }\end{array}$ & $\begin{array}{l}\text { Standard } \\
\text { Deviation }\end{array}$ & $\begin{array}{c}\text { Coefficient of } \\
\text { Variation }\end{array}$ & Ranking \\
\hline AB Bank Ltd. & 42 & 10.5 & 8.7 & $82.84 \%$ & Rank - 23 \\
\hline City BanK Ltd. & 78 & 19.5 & 6.76 & $34.66 \%$ & Rank - 10 \\
\hline Al Arafah Islami Bank Ltd. & 79.5 & 19.88 & 4.44 & $22.35 \%$ & Rank - 5 \\
\hline Social Islami Bank Ltd. & 77 & 19.25 & 9.91 & $51.49 \%$ & Rank -17 \\
\hline Pubali Bank Ltd. & 75 & 18.75 & 4.43 & $23.60 \%$ & Rank - 6 \\
\hline Premier Bank Ltd. & 29.5 & 7.38 & 0.75 & $10.17 \%$ & Rank - 1 \\
\hline Prime Bank Ltd. & 40 & 10 & 9.56 & $95.57 \%$ & Rank - 25 \\
\hline Exim Bank Ltd. & 45 & 11.25 & 9.74 & $86.60 \%$ & Rank - 24 \\
\hline Dutch Bangla Bank Ltd. & 95 & 23.75 & 4.99 & $21.02 \%$ & Rank - 4 \\
\hline Islami Bank BD Ltd. & 45 & 11.25 & 11.79 & $104.77 \%$ & Rank - 26 \\
\hline National Bank Ltd. & 80 & 20 & 6.68 & $33.42 \%$ & Rank - 9 \\
\hline IFIC Bank Ltd. & 56 & 14 & 9.49 & $67.76 \%$ & Rank - 20 \\
\hline Rupali Bank Ltd. & 15 & 3.75 & 5.5 & $146.67 \%$ & Rank - 28 \\
\hline Uttara Bank Ltd. & 62.5 & 15.63 & 6.52 & $41.75 \%$ & Rank - 12 \\
\hline Eastern Bank Ltd. & 51.5 & 12.88 & 6.88 & $53.47 \%$ & Rank - 18 \\
\hline Dhaka Bank Ltd. & 52 & 13 & 9.63 & $74.05 \%$ & Rank - 21 \\
\hline NCC Bank Ltd. & 52 & 13 & 5.35 & $41.19 \%$ & Rank - 11 \\
\hline Standard Bank Ltd. & 88 & 22 & 10.68 & $48.53 \%$ & Rank - 16 \\
\hline Mutual Trust Bank Ltd. & 67 & 16.75 & 5.44 & $32.47 \%$ & Rank - 7 \\
\hline South East Bank Ltd. & 63.5 & 15.88 & 3.12 & $19.65 \%$ & Rank - 3 \\
\hline One Bank Ltd. & 87 & 21.75 & 2.22 & $10.20 \%$ & Rank - 2 \\
\hline Shahjalal Islami Bank Ltd. & 42 & 10.5 & 6.03 & $57.41 \%$ & Rank - 19 \\
\hline Jamuna Bank Ltd. & 55 & 13.75 & 6.65 & $48.38 \%$ & Rank - 15 \\
\hline Brack Bank Ltd. & 69 & 17.25 & 8.3 & $48.13 \%$ & Rank - 14 \\
\hline Trust Bank Ltd. & 55 & 13.75 & 10.24 & $74.49 \%$ & Rank - 22 \\
\hline First Security Islami Bank Ltd. & 27 & 6.75 & 8.92 & $132.16 \%$ & Rank - 27 \\
\hline Bank Asia Ltd. & 60 & 15 & 6.98 & $46.51 \%$ & Rank - 13 \\
\hline Mercantile Bank Ltd. & 35.5 & 8.88 & 2.95 & $33.29 \%$ & Rank - 8 \\
\hline
\end{tabular}




\section{Appendix - 7}

\begin{tabular}{|c|c|c|c|c|c|}
\hline \multirow{2}{*}{ Name of the Banks } & \multicolumn{5}{|c|}{ Banks Financial Performance (Based on Market Ratio and Value Added Metrics) } \\
\hline & Total Point Score & $\begin{array}{l}\text { Mean } \\
\text { Score }\end{array}$ & $\begin{array}{c}\text { Standard } \\
\text { Deviation }\end{array}$ & $\begin{array}{l}\text { Coefficient of } \\
\text { Variation }\end{array}$ & Ranking \\
\hline AB Bank Ltd. & 74 & 12.33 & 10.46 & $84.83 \%$ & Rank - 26 \\
\hline City BanK Ltd. & 95 & 15.83 & 9.06 & $57.23 \%$ & Rank - 21 \\
\hline Al Arafah Islami Bank Ltd. & 89 & 14.83 & 5.12 & $34.52 \%$ & Rank - 7 \\
\hline Social Islami Bank Ltd. & 82.50 & 13.75 & 6.18 & $44.95 \%$ & Rank - 12 \\
\hline Pubali Bank Ltd. & 92 & 15.33 & 5.01 & $32.68 \%$ & Rank - 6 \\
\hline Premier Bank Ltd. & 37.50 & 6.25 & 3.49 & $55.84 \%$ & Rank - 19 \\
\hline Prime Bank Ltd. & 95 & 15.83 & 8.42 & $53.19 \%$ & Rank - 16 \\
\hline Exim Bank Ltd. & 45 & 7.50 & 5.62 & $74.93 \%$ & Rank - 24 \\
\hline Dutch Bangla Bank Ltd. & 144 & 24 & 4.69 & $19.54 \%$ & Rank - 2 \\
\hline Islami Bank BD Ltd. & 103.50 & 17.25 & 9.86 & $57.16 \%$ & Rank - 20 \\
\hline National Bank Ltd. & 46.50 & 7.75 & 7.47 & $96.39 \%$ & Rank - 28 \\
\hline IFIC Bank Ltd. & 117 & 19.5 & 7.11 & $36.46 \%$ & Rank - 10 \\
\hline Rupali Bank Ltd. & 91 & 15.17 & 13.53 & $89.19 \%$ & Rank - 27 \\
\hline Uttara Bank Ltd. & 106 & 17.67 & 6.53 & $36.96 \%$ & Rank - 11 \\
\hline Eastern Bank Ltd. & 110 & 18.33 & 8.26 & $45.06 \%$ & Rank - 13 \\
\hline Dhaka Bank Ltd. & 108.50 & 18.08 & 4.25 & $23.51 \%$ & Rank - 3 \\
\hline NCC Bank Ltd. & 30.50 & 5.08 & 2.62 & $51.57 \%$ & Rank - 14 \\
\hline Standard Bank Ltd. & 75 & 12.50 & 6.83 & $54.64 \%$ & Rank - 18 \\
\hline Mutual Trust Bank Ltd. & 102.50 & 17.08 & 6.2 & $36.30 \%$ & Rank - 8 \\
\hline South East Bank Ltd. & 92 & 15.33 & 10.17 & $66.34 \%$ & Rank - 22 \\
\hline One Bank Ltd. & 95.50 & 15.92 & 8.53 & $53.58 \%$ & Rank - 17 \\
\hline Shahjalal Islami Bank Ltd. & 82 & 13.67 & 7.04 & $51.50 \%$ & Rank - 15 \\
\hline Jamuna Bank Ltd. & 66.50 & 11.08 & 9.1 & $82.13 \%$ & Rank - 25 \\
\hline Brack Bank Ltd. & 150 & 25 & 2.97 & $11.88 \%$ & Rank - 1 \\
\hline Trust Bank Ltd. & 112 & 18.67 & 5.39 & $28.87 \%$ & Rank - 5 \\
\hline First Security Islami Bank Ltd. & 56 & 9.33 & 6.56 & $70.31 \%$ & Rank - 23 \\
\hline Bank Asia Ltd. & 78 & 13 & 3.69 & $28.38 \%$ & Rank - 4 \\
\hline Mercantile Bank Ltd. & 59.50 & 9.92 & 3.61 & $36.39 \%$ & Rank - 9 \\
\hline
\end{tabular}




\section{Appendix - 8}

\begin{tabular}{|c|c|c|c|c|c|}
\hline \multirow{2}{*}{ Name of the Banks } & \multicolumn{5}{|c|}{ Banks Financial Performance (Considering All Types of Ratio) } \\
\hline & Total Point Score & $\begin{array}{l}\text { Mean } \\
\text { Score }\end{array}$ & $\begin{array}{c}\text { Standard } \\
\text { Deviation }\end{array}$ & $\begin{array}{c}\text { Coefficient of } \\
\text { Variation }\end{array}$ & Ranking \\
\hline AB Bank Ltd. & 163.00 & 12.54 & 9.42 & $75.12 \%$ & Rank - 24 \\
\hline City BanK Ltd. & 240.00 & 18.46 & 7.31 & $39.60 \%$ & Rank - 6 \\
\hline Al Arafah Islami Bank Ltd. & 201.50 & 15.50 & 6.44 & $41.55 \%$ & Rank - 8 \\
\hline Social Islami Bank Ltd. & 201.50 & 15.50 & 7.48 & $48.26 \%$ & Rank - 15 \\
\hline Pubali Bank Ltd. & 224.00 & 17.23 & 5.08 & $29.48 \%$ & Rank - 2 \\
\hline Premier Bank Ltd. & 75.00 & 5.77 & 3.00 & $51.99 \%$ & Rank - 17 \\
\hline Prime Bank Ltd. & 194.00 & 14.92 & 8.30 & $55.63 \%$ & Rank - 19 \\
\hline Exim Bank Ltd. & 138.00 & 10.62 & 8.02 & $75.52 \%$ & Rank - 25 \\
\hline Dutch Bangla Bank Ltd. & 303.00 & 23.31 & 5.74 & $24.62 \%$ & Rank - 1 \\
\hline Islami Bank BD Ltd. & 213.50 & 16.42 & 9.92 & $60.41 \%$ & Rank - 20 \\
\hline National Bank Ltd. & 159.50 & 12.27 & 8.72 & $71.07 \%$ & Rank - 22 \\
\hline IFIC Bank Ltd. & 205.00 & 15.77 & 7.99 & $50.67 \%$ & Rank - 16 \\
\hline Rupali Bank Ltd. & 144.00 & 11.08 & 11.69 & $105.51 \%$ & Rank - 28 \\
\hline Uttara Bank Ltd. & 221.50 & 17.04 & 6.15 & $36.09 \%$ & Rank - 5 \\
\hline Eastern Bank Ltd. & 222.50 & 17.12 & 7.42 & $43.34 \%$ & Rank - 11 \\
\hline Dhaka Bank Ltd. & 198.50 & 15.27 & 6.33 & $41.45 \%$ & Rank - 7 \\
\hline NCC Bank Ltd. & 120.50 & 9.27 & 7.21 & $77.78 \%$ & Rank - 26 \\
\hline Standard Bank Ltd. & 175.00 & 13.47 & 9.76 & $72.46 \%$ & Rank - 23 \\
\hline Mutual Trust Bank Ltd. & 193.50 & 14.89 & 6.84 & $45.94 \%$ & Rank - 12 \\
\hline South East Bank Ltd. & 217.50 & 16.73 & 7.19 & $42.98 \%$ & Rank - 10 \\
\hline One Bank Ltd. & 217.50 & 16.73 & 7.00 & $41.84 \%$ & Rank - 9 \\
\hline Shahjalal Islami Bank Ltd. & 160.00 & 12.31 & 6.63 & $53.86 \%$ & Rank - 18 \\
\hline Jamuna Bank Ltd. & 172.50 & 13.27 & 8.47 & $63.83 \%$ & Rank - 21 \\
\hline Brack Bank Ltd. & 276.00 & 21.23 & 6.72 & $31.65 \%$ & Rank - 3 \\
\hline Trust Bank Ltd. & 200.00 & 15.39 & 7.14 & $46.39 \%$ & Rank - 14 \\
\hline First Security Islami Bank Ltd. & 112.00 & 8.62 & 8.30 & $96.29 \%$ & Rank - 27 \\
\hline Bank Asia Ltd. & 190.00 & 14.62 & 4.75 & $32.49 \%$ & Rank - 4 \\
\hline Mercantile Bank Ltd. & 139.00 & 10.70 & 4.95 & $46.26 \%$ & Rank - 13 \\
\hline
\end{tabular}




\section{Appendix - 9}

\begin{tabular}{|c|c|c|c|c|c|c|}
\hline \multicolumn{9}{|c|}{ Tests of Normality } \\
\hline & \multicolumn{3}{|c|}{ Kolmogorov-Smirnov $^{\mathrm{a}}$} & \multicolumn{3}{c|}{ Shapiro-Wilk } \\
\cline { 2 - 8 } & Statistic & Df & Sig. & Statistic & df & Sig. \\
\hline Return on Assets & .120 & 28 & $.200^{*}$ & .972 & 28 & .630 \\
Return on Investment & .116 & 28 & $.200^{*}$ & .954 & 28 & .244 \\
Return on Equity & .076 & 28 & $.200^{*}$ & .976 & 28 & .738 \\
Net Interest Margin & .176 & 28 & .027 & .820 & 28 & .000 \\
Earnings Per Share & .307 & 28 & .000 & .502 & 28 & .000 \\
Price Earnings Ratio & .253 & 28 & .000 & .609 & 28 & .000 \\
Book Value Per Share & .219 & 28 & .001 & .675 & 28 & .000 \\
Economic Value Added & .111 & 28 & $.200^{*}$ & .936 & 28 & .087 \\
Market Value Added & .169 & 28 & .038 & .932 & 28 & .068 \\
Tobin's Q & .359 & 28 & .000 & .400 & 28 & .000 \\
Net Asset Value Per Share & .223 & 28 & .001 & .733 & 28 & .000 \\
Market Capitalization & .172 & 28 & .033 & .772 & 28 & .000 \\
Dividend Yield\% & .157 & 28 & .075 & .928 & 28 & .055 \\
\hline
\end{tabular}

*. This is a lower bound of the true significance.

a. Lilliefors Significance Correction

\begin{tabular}{|c|c|c|c|c|c|}
\hline \multicolumn{6}{|c|}{ Skewness and Kurtosis Values of Variables } \\
\hline & \multirow{2}{*}{$\frac{\mathrm{N}}{\text { Statistic }}$} & \multicolumn{2}{|c|}{ Skewness } & \multicolumn{2}{|c|}{ Kurtosis } \\
\hline & & Statistic & Std. Error & Statistic & Std. Error \\
\hline Return on Assets (ROA) & 28 & .290 & .441 & .564 & .858 \\
\hline Return on Investment (ROI) & 28 & .222 & .441 & 1.015 & .858 \\
\hline Net Interest Margin ( NIM) & 28 & 2.130 & .441 & 7.131 & .858 \\
\hline Earnings Per Share (EPS) & 28 & 4.336 & .441 & 21.224 & .858 \\
\hline Price Earnings Ratio (P/E) & 28 & 3.459 & .441 & 14.368 & .858 \\
\hline Book Value Per Share (BVPS) & 28 & 3.260 & .441 & 14.322 & .858 \\
\hline Economic Value Added (EVA) & 28 & .956 & .441 & .846 & .858 \\
\hline Tobin's Q & 28 & 4.685 & .441 & 23.343 & .858 \\
\hline Net Asset Value Per Share (NAVPS) & 28 & 2.717 & .441 & 9.735 & .858 \\
\hline Market Capitalization & 28 & 2.226 & .441 & 5.925 & .858 \\
\hline Dividend Yield\% & 28 & .060 & .441 & -.972 & .858 \\
\hline Valid N (listwise) & 28 & & & & \\
\hline
\end{tabular}

\section{Appendix-10}

The correlation coefficients show the magnitude - strong, weak - , and direction - positive or negative of the relationships. The higher the coefficient value the stronger the relationship is and vice-versa.

Rank Correlation Coefficient Between Economic Value Added (EVA) and Return on Assets (ROA)

\begin{tabular}{|c|c|c|c|c|}
\hline & & & EVA & ROA \\
\hline \multirow{6}{*}{ Spearman's rho } & \multirow{3}{*}{ EVA } & Correlation Coefficient & 1.000 & $.524^{* *}$ \\
\hline & & Sig. (2-tailed) & . & .004 \\
\hline & & $\mathrm{N}$ & 28 & 28 \\
\hline & \multirow{3}{*}{ ROA } & Correlation Coefficient & $.524^{* *}$ & 1.000 \\
\hline & & Sig. (2-tailed) & .004 & . \\
\hline & & $\mathrm{N}$ & 28 & 28 \\
\hline
\end{tabular}

**. Correlation is significant at the 0.01 level (2-tailed). 
Rank Correlation Coefficient Between Economic Value Added (EVA) and Return on Investment (ROI)

\begin{tabular}{|lcc|c|c|}
\hline & & & EVA & ROI \\
\hline & & & 1.000 & .119 \\
& EVA & Correlation Coefficient &. & .545 \\
Spearman's rho & & Sig. (2-tailed) & 28 & 28 \\
& & $\mathrm{~N}$ & .119 & 1.000 \\
& ROI & Correlation Coefficient & .545 &. \\
& & Sig. (2-tailed) & $\mathrm{N}$ & 28 \\
\hline
\end{tabular}

Rank Correlation Coefficient Between Economic Value Added (EVA) and Return on Equity (ROE)

\begin{tabular}{|c|c|c|c|c|}
\hline & & & EVA & ROE \\
\hline \multirow{6}{*}{ Spearman's rho } & \multirow{3}{*}{ EVA } & Correlation Coefficient & 1.000 & $.645^{* *}$ \\
\hline & & Sig. (2-tailed) & . & .000 \\
\hline & & $\mathrm{N}$ & 28 & 28 \\
\hline & \multirow{3}{*}{$\mathrm{ROE}$} & Correlation Coefficient & $.645^{* *}$ & 1.000 \\
\hline & & Sig. (2-tailed) & .000 & $\cdot$ \\
\hline & & $\mathrm{N}$ & 28 & 28 \\
\hline
\end{tabular}

**. Correlation is significant at the 0.01 level (2-tailed).

Rank Correlation Coefficient Between Economic Value Added (EVA) and Net Interest Margin (NIM)

\begin{tabular}{|c|c|c|c|c|}
\hline & & & EVA & NIM \\
\hline \multirow{6}{*}{ Spearman's rho } & \multirow{3}{*}{ EVA } & Correlation Coefficient & 1.000 & .250 \\
\hline & & Sig. (2-tailed) & . & .200 \\
\hline & & $\mathrm{N}$ & 28 & 28 \\
\hline & \multirow{3}{*}{ NIM } & Correlation Coefficient & .250 & 1.000 \\
\hline & & Sig. (2-tailed) & .200 & . \\
\hline & & $\mathrm{N}$ & 28 & 28 \\
\hline
\end{tabular}

Rank Correlation Coefficient Between Economic Value Added (EVA) and Earnings per Share (EPS)

\begin{tabular}{|lcc|c|c|}
\hline & & & EVA & EPS \\
\hline & & Correlation Coefficient & 1.000 & $.421^{*}$ \\
EVA & Sig. (2-tailed) &. & .026 \\
& & $\mathrm{~N}$ & 28 & 28 \\
& & Correlation Coefficient & $.421^{*}$ & 1.000 \\
& EPS & Sig. (2-tailed) & .026 &. \\
& & $\mathrm{~N}$ & 28 & 28 \\
\hline
\end{tabular}

*. Correlation is significant at the 0.05 level (2-tailed).

Rank Correlation Coefficient Between Economic Value Added (EVA) and Price Earnings Ratio (P/E Ratio)

\begin{tabular}{|lcc|c|c|}
\hline & & & EVA & P/E Ratio \\
\hline & \multirow{2}{*}{ EVA } & Correlation Coefficient & 1.000 & $-.384^{*}$ \\
& & Sig. (2-tailed) &. & .044 \\
Spearman's rho & & $\mathrm{N}$ & 28 & 28 \\
& & Correlation Coefficient & $-.384^{*}$ & 1.000 \\
& P/E Ratio & Sig. (2-tailed) & .044 &. \\
& & $\mathrm{~N}$ & 28 & 28 \\
\hline
\end{tabular}

*. Correlation is significant at the 0.05 level (2-tailed). 
Rank Correlation Coefficient Between Economic Value Added (EVA) and Dividend Yield \%

\begin{tabular}{|c|c|c|c|c|}
\hline & & & EVA & Dividend Yield \% \\
\hline \multirow{6}{*}{ Spearman's rho } & \multirow{3}{*}{ EVA } & Correlation Coefficient & 1.000 & .082 \\
\hline & & Sig. (2-tailed) & . & .680 \\
\hline & & $\mathrm{N}$ & 28 & 28 \\
\hline & \multirow{3}{*}{ Dividend Yield \% } & Correlation Coefficient & .082 & 1.000 \\
\hline & & Sig. (2-tailed) & .680 & . \\
\hline & & $\mathrm{N}$ & 28 & 28 \\
\hline
\end{tabular}

Rank Correlation Coefficient Between Economic Value Added (EVA) and Tobin's Q

\begin{tabular}{|c|c|c|c|c|}
\hline & & & EVA & Tobin's Q \\
\hline \multirow{6}{*}{ Spearman's rho } & \multirow{3}{*}{ EVA } & Correlation Coefficient & 1.000 & .058 \\
\hline & & Sig. (2-tailed) & . & .771 \\
\hline & & $\mathrm{N}$ & 28 & 28 \\
\hline & \multirow{3}{*}{ Tobin's Q } & Correlation Coefficient & .058 & 1.000 \\
\hline & & Sig. (2-tailed) & .771 & . \\
\hline & & $\mathrm{N}$ & 28 & 28 \\
\hline
\end{tabular}

Rank Correlation Coefficient Between Economic Value Added (EVA) and Net Profit

\begin{tabular}{|lcc|c|c|}
\hline & & & EVA & Net Profit \\
\hline & \multirow{2}{*}{ EVA } & Correlation Coefficient & 1.000 & .340 \\
Spearman's rho & & Sig. (2-tailed) &. & .076 \\
& & $\mathrm{~N}$ & 28 & 28 \\
& \multirow{2}{*}{ Net Profit } & Correlation Coefficient & .340 & 1.000 \\
& & Sig. (2-tailed) & .076 &. \\
& & $\mathrm{~N}$ & 28 & 28 \\
\hline
\end{tabular}

\section{Appendix -11}

\begin{tabular}{|c|c|c|c|c|c|}
\hline Name of the Banks & $\begin{array}{c}\text { Market Capitalization } \\
\text { (BDT in million) }\end{array}$ & Weight & Name of the Banks & $\begin{array}{c}\text { Market Capitalization } \\
\text { (BDT in million) }\end{array}$ & Weight \\
\hline AB Bank Ltd. & $12,519.45$ & $0.40 \%$ & Dhaka Bank Ltd. & $12,319.68$ & $0.39 \%$ \\
\hline City BanK Ltd. & $17,866.28$ & $0.57 \%$ & NCC Bank Ltd. & $7,304.21$ & $0.23 \%$ \\
\hline Al Arafah Islami Bank Ltd. & $13,920.29$ & $0.32 \%$ & Standard Bank Ltd. & 6032.82 & $0.23 \%$ \\
\hline Social Islami Bank Ltd. & $10,125.24$ & $0.44 \%$ & Mutual Trust Bank Ltd. & $7,201.66$ & $0.19 \%$ \\
\hline Pubali Bank Ltd. & $19,016.07$ & $0.60 \%$ & South East Bank Ltd. & $16,184.18$ & $0.51 \%$ \\
\hline Premier Bank Ltd. & $5,208.62$ & $0.16 \%$ & One Bank Ltd. & 9025.85 & $0.29 \%$ \\
\hline Prime Bank Ltd. & 18,631 & $0.59 \%$ & Shahjalal Islami Bank Ltd. & 9918.29 & $0.31 \%$ \\
\hline Exim Bank Ltd. & $12,145.36$ & $0.38 \%$ & Jamuna Bank Ltd. & 7424.70 & $0.23 \%$ \\
\hline Islami Bank BD Ltd. & $44,757.74$ & $1.42 \%$ & Trust Bank Ltd. & $11,298.73$ & $0.36 \%$ \\
\hline National Bank Ltd. & $16,146.57$ & $0.51 \%$ & First Security Islami Bank Ltd. & $5,974.09$ & $0.19 \%$ \\
\hline IFIC Bank Ltd. & $10,672.34$ & $0.34 \%$ & Bank Asia Ltd. & $13,848.45$ & $0.44 \%$ \\
\hline Rupali Bank Ltd. & $7,753.09$ & $0.25 \%$ & Mercantile Bank Ltd. & $7,908.98$ & $0.25 \%$ \\
\hline Uttara Bank Ltd. & $9,081.82$ & $0.29 \%$ & Eastern Bank Ltd. & 17479.74 & $0.55 \%$ \\
\hline
\end{tabular}




\section{REFERENCES}

[1] Ongore VO, Kusa GB. Determinants of financial performance of commercial banks in Kenya. International Journal of Economics and Financial Issues. 2013 Jan 1;3 (1):237-252.

[2] Parasuraman NR. Economic Value Added: Its Computation and Impact on Select Banking Companies. The Icfai Journal of Applied Finance. 2000 Jan; 6(4):14-30.

[3] Yeh QJ. The application of data envelopment analysis in conjunction with financial ratios for bank performance evaluation. Journal of the Operational Research Society. 1996 Aug 1; 47(8):980-988.

[4] Webb R. Levels of efficiency in UK retail banks: a DEA window analysis. Int. J. of the economics of business. 2003 Nov $1 ; 10(3): 305-322$

[5] Lacewell SK. Do efficient institutions score well using ratio analysis? An examination of commercial banks in the 1990s. Journal of Commercial Banking and Finance. 2003 Jan 1; 2:17-34.

[6] Halkos GE, Salamouris DS. Efficiency measurement of the Greek commercial banks with the use of financial ratios: a data envelopment analysis approach. Management Accounting Research. 2004 Jun 30; 15(2):201-224.

[7] Tarawneh MA comparison of financial performance in the banking sector: Some Evidence from Omani Commercial Banks. International Research Journal of Finance and Economics. 2006; 3(3):101-112.

[8] Yalcin N, Bayrakdaroglu A, Kahraman C. Application of fuzzy multi-criteria decision making methods for financial performance evaluation of Turkish manufacturing industries. Expert Systems with Applications. 2012 Jan 31;39(1):350-364.

[9] Khrawish H.A. Determinants of Commercial Banks Performance: Evidence from Jordan. International Research Journal of Finance and Economics. 2011; 5(5): 19-45.

[10] Moyer RC, McGuigan JR, Rao RP, Kretlow WJ. Contemporary financial management. Nelson Education; 2011 Jan 25.

[11] Wen W. Ownership Structure and Banking Performance: New Evidence in China. Universitat Autònoma de Barcelona Departament D'economia de L'empresa. 2010 Sep; 24.

[12] Kieso DE, Weygandt JJ, Warfield TD. Intermediate Accounting (Terjemahan). 10th ed. New York: John Willey \& Sons, 2001.pp. 270-280.

[13] Alkhatib A, Harasheh M. Financial performance of Palestinian commercial banks. International Journal of business and social science. 2012 Feb 15; 3(3):175-184.

[14] Brewer PC, Chandra G, Hock CA. Economic value added (EVA): Its uses and limitations. SAM Advanced Management Journal. 1999 Apr 1; 64(2):4-10.

[15] Kramer JK, Peters JR. An interindustry analysis of economic value added as a proxy for market value added. Journal of Applied Finance. 2001 Jan; 11(1):41-49.

[16] Hartman JC. On the equivalence of net present value and market value added as measures of a project's economic worth. The Engineering Economist. 2000 Jan 1; 45(2):158-165.

[17] Stewart III GB. The Quest for Value (New York, est for Value HarperCollins).

[18] Ncube M. Efficiency of the Banking Sector in South Africa. African Economic Conference Fostering Development in an Era of Financial and Economic Crises, Addis Ababa. 2009.

[19] Samad A. Bahrain Commercial Bank's Performance during 1994-2001. Credit and Financial Management Review. 2004; 10(1):33-40.

[20] Van Horne JC, Wachowicz Jr. JM. Fundamentals of financial management, 11th ed. India: Pearson; 2005.pp. 125-168.

[21] Pandey IM. Financial statement analysis. Financial Management, 9th ed. New Delhi, India: Vikas; 2004. pp. 517-558.

[22] Khan AR. Sources and uses of funds, performance evaluation and bank failure. Bank Management: A fund Emphasis,(2nd edition), Dhaka: Decent Book House. 2009:51-68.

[23] Mujeri MK, Younus S. An analysis of interest rate spread in the banking sector in Bangladesh. The Bangladesh Development Studies. 2009 Dec 1:1-33.

[24] Chowdhury TA, Ahmed K. Performance evaluation of selected private commercial banks in Bangladesh. International journal of business and management. 2009 Mar $17 ; 4(4): 86-97$

[25] Duncan E, Elliott G. Efficiency, customer service and financial performance among Australian financial institutions. International Journal of bank marketing. 2004 Aug 1; 22(5):319-342.

[26] Almazari AA. Financial performance evaluation of some selected Jordanian commercial banks. International Research Journal of Finance and Economics. 2011; 68(8):50-63.

[27] Ali K, Akhtar MF, Ahmed HZ. Bank-specific and macroeconomic indicators of profitability-empirical evidence from the commercial banks of Pakistan. International Journal of Business and Social Science. 2011; 2(6):235-242.

[28] Siddiqui MA, Shoaib A. Measuring performance through capital structure: Evidence from banking sector of Pakistan. African Journal of Business Management 2011; 5(5): 1871-1879.

[29] Kiyota H. Efficiency of commercial banks in Sub-Saharan Africa: A comparative analysis of domestic and foreign banks. In a paper prepared for the CSAE conference 2009 Mar.

[30] Kirkpatrick C, Murinde V, Tefula M. The measurement and determinants of $\mathrm{x}$-inefficiency in commercial banks in Sub-Saharan Africa. The European Journal of Finance. 2008 Oct $1 ; 14(7): 625-639$.

[31] Okeahalam CC. Production efficiency in the South African banking sector: A stochastic analysis. International Review of Applied Economics. 2006 Jan 1; 20(1):103-123.

[32] Cronje JJ. Assessing the relative efficiency management of South African banks. Management Dynamics. 2007 Oct 1; 16(4):11-23.

[33] Jahur JS, Riyadh A. Economic Value Added as a Management 
Tool-A Study on Selected Banking Companies in Bangladesh. Bank Posikrama. 2002; 27(1):46-63.

[34] Shill SC. Performance Measures: An Application of Economic Value Added. International Journal of Business and Management 2009; 4(3): 169-177.

[35] Bowen HP, Wiersema MF. Matching method to paradigm in strategy research: Limitations of cross-sectional analysis and some methodological alternatives. Strategic management journal. 1999 Jul 1; 20(7):625-636.

[36] Hempel G, Simonson D, Coleman, A. Bank Management: Text and Cases. 4th ed. John Wiley \& Sons, Inc. 1994, pp. 21-30.

[37] Dietrich JK. Financial services and financial institutions: Value creation in theory and practice. Prentice Hall; 1996.

[38] Levin IR, Rubin DS. Nonparametric methods. Statistics for Management, 7th ed. India: Pearson, 2007. pp. $791-859$.
[39] Shapiro SS, Wilk MB. An analysis of variance test for normality (complete samples). Biometrika. 1965 Dec 1; 52(3/4):591-611.

[40] Razali NM, Wah YB. Power comparisons of shapiro-wilk, kolmogorov-smirnov, lilliefors and anderson-darling tests. Journal of statistical modeling and analytics. 2011;2(1):21-33

[41] Cramer D. Fundamental statistics for social research: step-by-step calculations and computer techniques using SPSS for Windows. Psychology Press; 1998.

[42] Cramer D, Howitt DL. The Sage dictionary of statistics: a practical resource for students in the social sciences. Sage; 2004 May 18.

[43] Doane DP, Seward LE. Measuring skewness: a forgotten statistic. Journal of Statistics Education. 2011; 19(2):1-18.

[44] India RB. REPORT ON TREND AND PROGRESS OF BANKING IN INDIA 2014-15. 